\title{
10 years recurrence of an oral intramuscular lipoma: case report
}

\author{
Recidiva de lipoma intramuscular bucal após 10 anos: \\ relato de caso \\ La recurrencia de lipoma intramuscular bucal después de 10 años: \\ reporte de caso \\ Bruna da Fonseca WASTNER ${ }^{1}$ \\ Mariela VERONESE ${ }^{2}$ \\ Juliana Lucena SCHUSSEL ${ }^{1,3}$ \\ William Phillip Pereira da SILVA ${ }^{\mathbf{1 , 5}}$ \\ Juliana Elizabeth JUNG ${ }^{4}$ \\ Laurindo Moacir SASSI ${ }^{1}$ \\ ${ }^{1}$ Department of Oral and Maxillofacial Surgery, Erasto Gaertner Hospital, Curitiba, Paraná, Brazil \\ ${ }^{2}$ Universidade Positivo, Curitiba, Paraná, Brazil \\ ${ }^{3}$ Universidade Federal do Paraná, Department of Stomatology. Curitiba, Paraná, Brazil \\ ${ }^{4}$ Department of Pathology, Erasto Gaertner Hospital, Curitiba, Paraná, Brazil \\ ${ }^{5}$ Universidade Estadual Paulista - UNESP/FOA, Department of Oral and Maxillofacial Surgery, Araçatuba, São Paulo, Brazil
}

\begin{abstract}
Intramuscular lipomas are a variant of benign lipomas that emerge inside skeletal muscle fibres at different locations and present a high recurrence rate, when not properly treated. We report a case of an oral intramuscular lipoma in 61 years old female patient that recurred 10 years after the first surgery. The authors discuss the need for a more aggressive surgical approach and highlight the importance of long-term follow-up.

Descriptors: Lipoma; Mouth Neoplasms; Mouth.
\end{abstract}

\section{Resumo}

Os lipomas intramusculares são uma variante de lipomas benignos que emergem dentro das fibras musculares esqueléticas em locais diferentes e apresentam alta taxa de recorrência, quando não são devidamente tratados. Relatamos um caso de lipoma intramuscular bucal em paciente de 61 anos de idade que recidivou 10 anos após a primeira cirurgia. Os autores discutem a necessidade de uma abordagem cirúrgica mais agressiva e destacam a importância do acompanhamento de longo prazo.

Descritores: Lipoma; Neoplasias Bucais; Boca.

\section{Resumen}

Los lipomas intramusculares son una variante de lipomas benignos que emergen dentro de las fibras musculares esqueléticas en lugares diferentes y presentan una alta tasa de recurrencia, cuando no son debidamente tratados. Se relató un caso de lipoma intramuscular bucal en paciente de 61 años de edad que recidivó 10 años después de la primera cirugía. Los autores discuten la necesidad de un abordaje quirúrgico más agresivo y destacan la importancia del seguimiento a largo plazo.

Descriptores: Lipoma; Neoplasias de la Boca; Boca.

\section{INTRODUCTION}

Lipoma is a benign tumour of mesenchymal origin consisting of mature adipocytes. This benign tumour, although common in the chest and extremities, it is quite rare in the oral cavity and oropharynx ${ }^{1}$, ranging from $1-4 \%$ of all benign oral tumours. Lipoma usually presents itself with uncertain aetiology and pathogenesis, but it is also described a hormonal and inflammatory influence and also hereditary factors ${ }^{1}$. The main clinical aspect is as a nodular mass of soft consistency of pedunculated or sessile base, with smooth and gelatinous appearance, well defined and asymptomatic, with slow growth rate, not ulcerated and that, in some cases, may present a fibrous capsule. The intraoral sites most affected are floor of the mouth, lip, tongue and buccal mucosa ${ }^{2}$. The diagnosis is primarily clinical, although imaging may be a helpful tool. Some of the histological variances of benign lipomas are fibrolipoma, osteolipoma, angiolipoma, condrolipoma, intramuscular and atypical lipoma ${ }^{3}$.

\section{CASE REPORT}

Female patient, leucoderma, 61 year old, attended the Department of Oral and Maxillofacial Surgery of Erasto Gaertner Hospital reporting an injury in the buccal mucosa of mandible, bilateral. The patient reported that 10 years before had a similar injury in the same region, which was surgically treated. Intraoral examination revealed the presence of nodular lesions in the mandible buccal mucosa, with approximately $30 \mathrm{~mm}$ on the left side and $10 \mathrm{~mm}$ on the right side, flaccid, painless and with smooth surface (Figure 1).

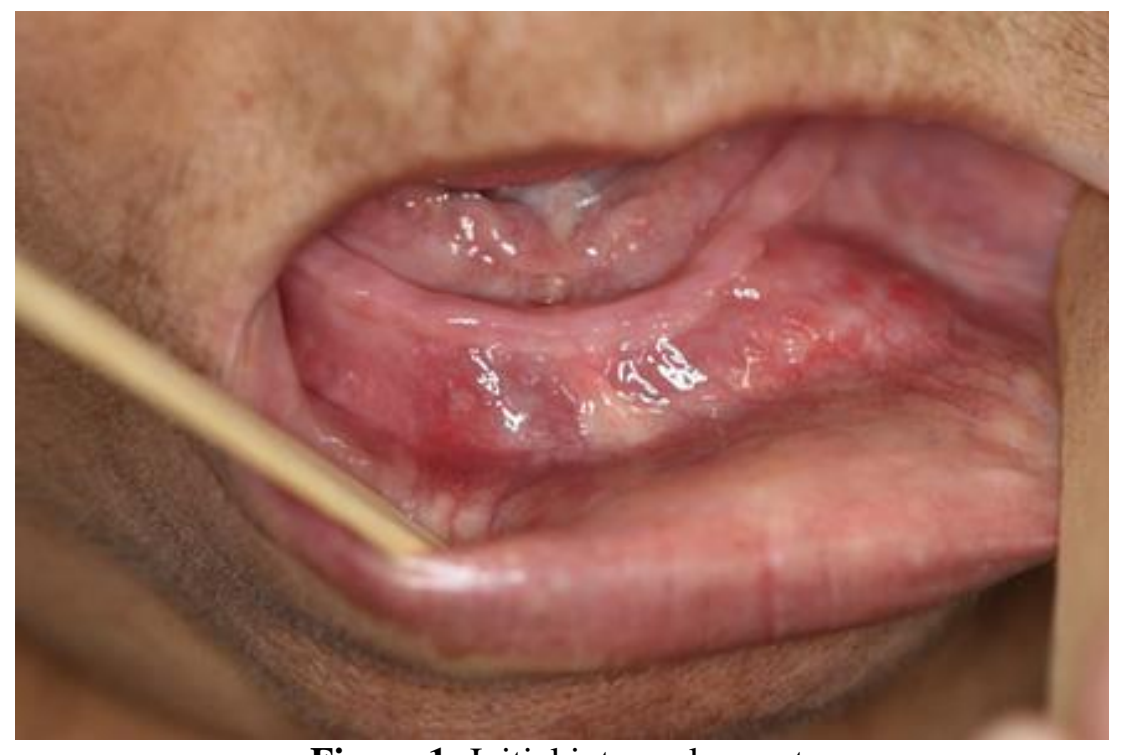

Figure 1: Initial intraoral aspect. 
CT scan showed a hypodense area on the mentual region (Figure 2). Excisional biopsy of the mass through an intraoral incision under general anaesthesia showed a soft, yellow mass firmly adherent within the muscle. Histological examination showed proliferation of mature adipocytes permeated by muscle fibers, with absence of mitosis and atypical cells (Figure 3). The histopathological diagnosis was intramuscular lipoma.

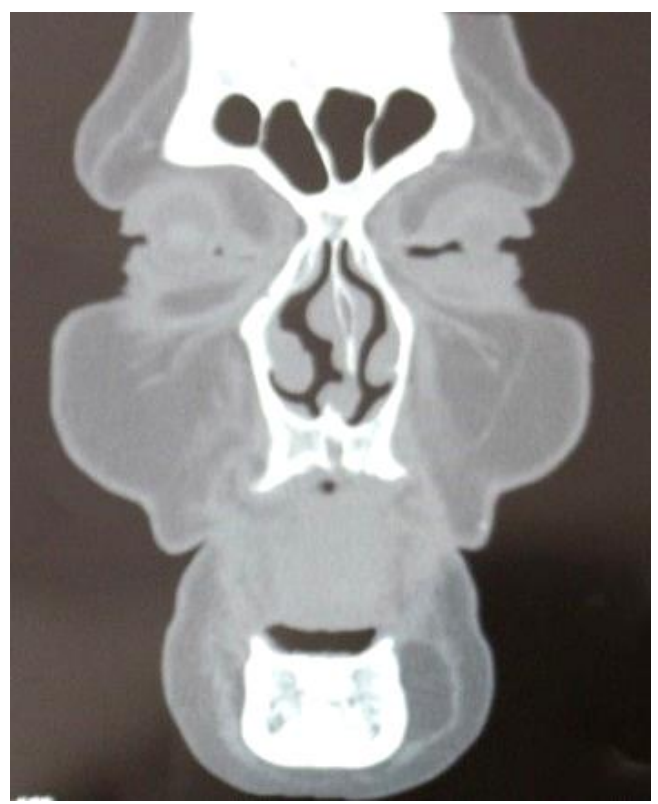

Figure 2: Preoperative CT scan - coronal view - showing hypodense lesion in the mental region, left side.

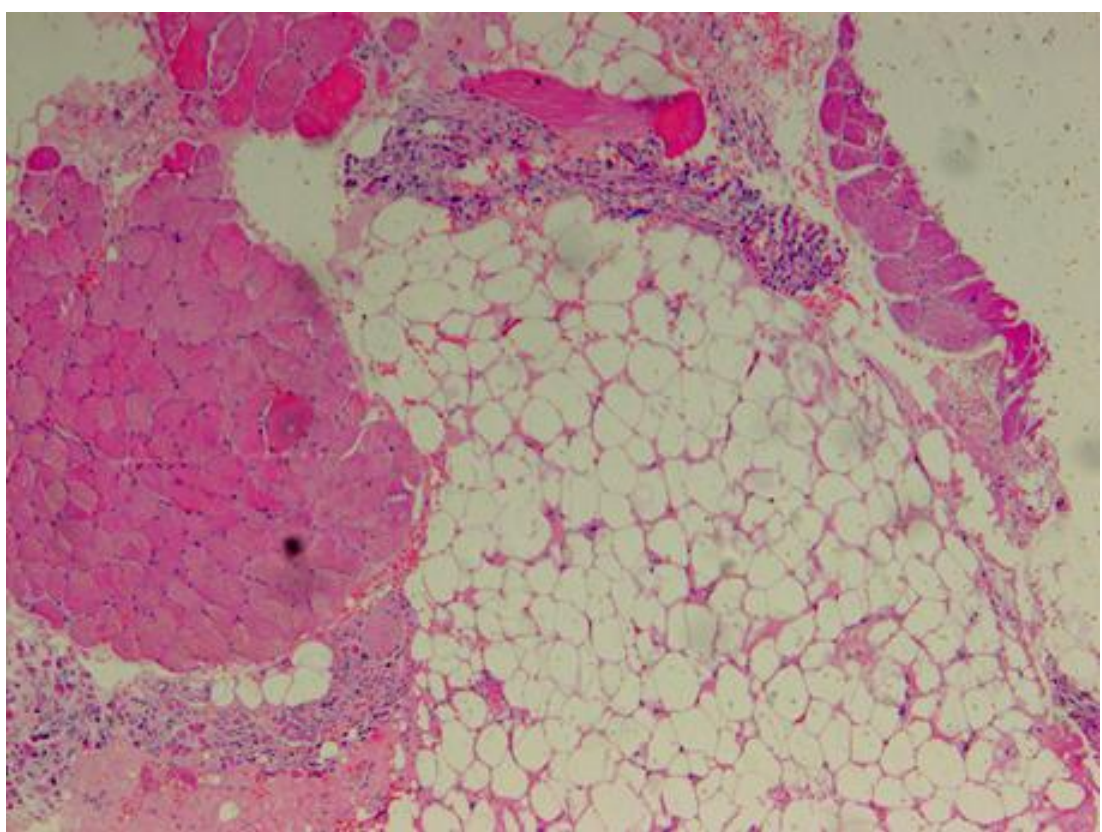

Figure 3: Non-encapsulated adipocytes proliferation permeated by muscle fibers.

\section{DISCUSSION}

Intramuscular lipoma emerges inside skeletal muscle fibres at different locations, i.e. temporal ${ }^{4}$ and masseter muscle $^{5}$, mainly during middle to late adulthood ${ }^{6}$. Although reported as an sporadic lesion, may be, in some cases, related inherited disorders as multiple lipomatosis, Gardner syndrome, Cowden syndrome, and Madelung disease ${ }^{7}$. On the case reported in this paper, there was no such relation observed. The differential diagnosis of intramuscular lipoma includes specially a well-differentiated liposarcoma. Again, in the present case, it was not observed lipoblastic proliferation, cellular pleomorphism or mitoses, which would raise the hypothesis of a liposarcoma ${ }^{8}$. Its recurrence rate has been reported to range between 19 and $62.5 \%$, usually happening 6-7.5 years after the excision, which highlights the rarity of the case reported here, that showed recurrence 10 years after surgery. No malignant changes have been reported for recurrent intramuscular lipomas ${ }^{9}$. This high recurrence rate cited above, according to the literature, is mainly due the difficulty of achieving complete surgical excision, since the masses are deeply situated, not encapsulated, and exhibit an infiltrative growth pattern. Even though a wide recurrence rate is described on the literature, only two cases of recurrent intramuscular lipoma on the oral cavity have been found in database ${ }^{10}$. One can discuss whether it is a true benign lesion, since it presents signs that suggest malignant behaviour, as the high recurrence rate and infiltration of adjacent musculature, already mentioned in this paper. Scolozzi et al. ${ }^{4}$ performed a cytogenetic analysis of an intramuscular lipoma of the masseter muscle and did not detect any significant genomic amplification, which prompted the confirmation of the benign nature of the tumour ${ }^{4}$. Being so, one may conclude that oral intramuscular lipoma is a pathology that required a more aggressive surgical excision in order to remove it completely, avoiding the risk of recurrence that may occur even a long time after the first treatment requiring long-term follow-up.

\section{REFERENCES}

1. Fregnani ER, Pires FR, Falzoni R, Lopes MA,Vargas PA. Lipomas of the oral cavity: clinical findings, histological classification and proliferative activity of 46 cases. Int J Oral Maxillofac Surg. 2003; 32(1):49-53.

2. Martorelli S, Gueiros LAM, Albert AJ, Albuquerque RS, Martorelli FO. Lipoma intraoral de tamanho incomum.Odontologia.Clín.-Científ. 2005; 4(1):57-62.

3. Bandeca MC, de Pádua JM, Nadalin MR, Ozório JE, Silva-Souza YT, da Cruz Perez DE. Oral soft tissue lipomas: a case series. J Can Dent Assoc. 2007; 73(5):431-4.

4. Scolozzi P, Lombardi T, Maire G, Pedeutour F, Richter M. Infiltrating intramuscular lipoma of the temporal muscle. A case report with molecular cytogenetic analysis. Oral Oncol. 2003; 39:316-22.

5. Tsumuraya G, Yamada H, Shimizu H, Hamada Y. Intramuscular lipoma in the masseter muscle: a case report. Br J Oral Maxillofac Surg. 2014; 52(4):e21-3.

6. Kleihues P, Sobin LH (eds). WHO classification of tumours In: Pathology and genetics of tumours of soft tissue and bone. Lyons: IARC Press; 2003.

7. EI-Monem MH, Gaafar AH, Magdy EA. Lipomas of the head and neck: Presentation variability and diagnostic work-up. J Laryngol Otol. 2006;120(1):4755.

8. Ohguri T, Aoki T, Hisaoka M, Watanabe H, Nakamura $\mathrm{K}$, Hashimoto $\mathrm{H}$ et al. Differential diagnosis of benign peripheral lipoma from well-differentiated liposarcoma on MR imaging: is comparison of margins and internal characteristics useful? AJR Am J Roentgenol 2003; 180(6):1689-94.

9. Dionne GP, Seemayer TA. Infiltrating lipoma and angiolipomas revisited. Cancer. 1974; 33(3):732-8.

10. Naruse $T$, Yanamoto $S$, Kawano $T$, Yoshitomi I, Yamada SI, Kawasaki G et al. Intramuscular lipoma of the tongue: Report of a case complicated with diffuse lipomatosis. J Oral Maxillofac Surg Med Pathol. 2012; 24(4):237-40. 


\section{CONFLICTS OF INTERESTS}

The authors declare no conflicts of interests.

\section{CORRESPONDING AUTHOR}

Bruna da Fonseca Wastner bru.wastner@hotmail.com

Received 02/08/2017

Accepted 31/08/2017 